\title{
İşsizlik süresine etki eden faktörlerin yaşam analizi yöntemleri ile araştırılması*?
}

\section{Investigation of the factors affecting the unemployment period with life analysis methods}

\section{Deniz Karapınar ${ }^{1}$}

Şebnem Zorlutuna ${ }^{2}$

1 Öğr. Gör. Giresun Üniversitesi, Alucra Turan Bulutçu MYO, Sağllk Kurumları İşletmeciliği,Türkiye, e-mail: deniz.karapinar@giresun.edu.tr 2 Dr. Öğr. Üyesi, Cumhuriyet Üniversitesi, İktisadi ve İdari Bilimler Fakültesi, Ekonometri Bölümü, Türkiye, e-mail: szorlutuna@cumhuriyet.edu.tr

\section{$\ddot{O} z$}

İşsizlik, çalışabilecek durumda olan ve çalışma isteğinde olan kişilerin bir bölümünün çeşitli sebeplerden dolayı işlerinin olmamasını ifade etmektedir. İşsizlik ülkelerin sosyal ve ekonomik durumlarına göre farklılıklar gösterse de çoğu ülkenin en fazla mücadele ettiği sorunlardan biri olarak karşılaşılmaktadır. Türkiye de yıllar itibari ile hemen hemen her dönem görülen yüksek işsizlik oranları ile mücadele eden bir ülkedir. Bu sebeple işsizlik süresini etkileyen faktörlerin araştırılması oldukça önemlidir.

Bu çalışmanın amacı; 2015-2018 yıllarına ait TÜIK Yaşam ve Gelir Araştırması Anketi verilerinden yararlanarak yılllk işsizlik süresine etki eden faktörleri, ortalama işsizlik süresini Yaşam Analizi Yöntemleri ile belirlemektir. Çalışmada, yaşam analizi ile bireylerin referans yılında ortalama işsiz kalma süreleri tahmin edilmiştir. Yaşam analizi yöntemlerinden Yaşam Tablosu yöntemi kullanılarak bireylerin işsiz kalma olasılıkları, Kaplan-Meier ve Cox Regresyon yöntemi ile ortalama işsizlik süresi ve işsizliğe etki eden faktörler belirlenmiştir.

Anahtar kelimeler: Yaşam Analizi, Kaplan-Meier, Cox Regresyon, İşsizlik Süresi, Yaşam Tablosu

JEL kodları: C14, C34, J64.

\begin{abstract}
Unemployment refers to the fact that some of the people who are able and willing to work do not have a job for various reasons. Although unemployment varies according to the social and ekonomic conditions of the countries, it is encountered as one of the problems most countries struggle with. Turkey is a country that struggles with high unemployment rates seen in almost every period over the years. For this reason, it is vey important to investigate the factors affecting the duration of unemployment.

The aim of this study; determine the factors affecting the annual unemployment duration, by using the Income and Living Condition Survey of Turkey Statistical Institute fort he year 2015-2018 with Life Analysis Methods.
\end{abstract}

*Bu çalışma, 8-10 Eylül 2021 tarihinde düzenlenen 21. Uluslararası Ekonometri, Yöneylem Araştırması ve İstatistik Sempozyumu’nda sözlü bildiri olarak sunulmuştur.

Citation/Atıf: Karapınar, D. \& Zorlutuna, Ş., (2022). İşsizlik süresine etki eden faktörlerin yaşam analizi yöntemleri ile araştırılması? Journal of Life Economics. 9(1): 1-19, DOI: $10.15637 /$ lecon.9.1.01

Corresponding Author/ Sorumlu Yazar:

Deniz Karapınar

E-mail: deniz.karapinar@giresun.edu.tr
Bu çalışma, Creative Commons Atıf 4.0 Uluslararası Lisansı ile lisanslanmıştır.

This work is licensed under a Creative Commons Attribution 4.0 International License. 
In the study, the avarage duration of unemployment in the reference year of individuals was estimated by life expectancy analysis. The probability of the individuals being unemplyment using the Life Table method, one of the life analysis methods, average unemployment duration and the factors affecting unemplyment wew determined with the Kaplan-Meier and Cox Regression method.

Keywords: Life Analysis, Kaplan-Meier, Cox Regression, Unemployment Period, Life Table

JEL codes: C14, C34, J64.

\section{GİRIŞ̧}

İşsizlik, geçmişten günümüze dek ülkelerin en çok mücadele ettiği problemlerden biri olarak karşımıza çıkmaktadır. Ülkeler sosyal ve ekonomik boyutları açısından birbirlerinden farklı olmasına rağmen çeşitli müdahaleler ile çözüm bulmaya çalıştıkları ortak sorunları işsizliktir. İşsizlik, aktif nüfus içinde olmasına rağmen herhangi bir işte çalışmayan, iş arayan ya da var olan işinden ayrılan bireylerin oluşturduğu duruma denilmektedir (Çelik, 2009: 143). Bu durum, işsiz bireyleri değer kaybına uğratırken ülke ekonomisini de önemli ölçüde üretim kaybına uğratmaktadır. Buna bağlı olarak meydana gelen milli gelir azalışı ekonomide eşitsizlikler yaratarak ülke istikrarını önemli ölçüde bozmaktadır (Apaydın, 2018: 161).

Çalışma isteğine ve gücüne sahip olup iş bulamayanların ya da mevcut işinden herhangi sebeple kendi arzusu dışında ayrılmak mecburiyetinde kalan bireylerin işsiz kalmaları hayatlarını büyük ölçüde etkilemektedir. Ancak bireylerin yalnız işsiz kalmaları değil, işsiz geçirdikleri süre de oldukça önem teşkil etmektedir. İşsizlik süresi arttıkça işsizliğin yıkıcı etkileri de artacak, kişi psikolojik yıkıma uğrayacak ve agresif tutumlar sergileyebilecektir. Uzayan süreçle birlikte kişinin iş bulma ümidi azalacak, işsizliğin toplumsal bir boyuta erişmesi kaçınılmaz hale gelecektir.

İşsizliğin günümüze dek ortaya çıkış sebepleri birbirinden farklılık göstermekle birlikte ülkelerin gelişmişlik düzeyleri de işsizliğin ortaya çıkmasında etkili olan sebeplerden biri olarak gösterilmektedir (Bulut, 2011: 9). Bu bağlamda, gelişmiş ülkelerdeki işsizlik, talep yetersizliğinden ve ekonomik dalgalanmalardan kaynaklanan, ekonomik istikrarsızlıklar sonucu konjonk- türel işsizlik şeklinde ortaya çıkmaktadır. Az gelişmiş ve gelişmekte olan ülkelerde ise işsizlik yapısına bakıldığında, sermaye yetersizliği sonucu ortaya çıkan işsizlik durumu söz konusudur. Ülkelerde yaşanan ekonomik gelişmeler, nüfus farklılıkları, nüfusun sektörel değişimleri, nüfus artış oranları ve toplumsal yapıların farklılıkları gibi etmenler gelişmiş ya da gelişmekte olan ülkelerde işsizlik sebeplerinin belirleyicileri olmaktadır (Ayvaz, 1990: 16).

İşsizlik, bireyin yaşı, cinsiyeti, eğitimi, medeni durumu, sağlık durumu gibi birçok faktörden de etkilenmektedir. Örneğin, toplumun en küçük yapı taşını oluşturan ailenin geçimini sağlayan bireyin işini kaybetmesi tüm aile fertlerini olumsuz yönde etkileyebilirken, birine bakmakla yükümlü olmayan, sadece kendi sorumluğunu taşıyan bir bireyin işsiz kalması aile reisi olarak adlandıracağımız kişilere göre daha az etkiye sahip olmaktadır. Yapılan birçok araştırmada işsizlik hali, 20-59 yaş aralığındaki kişileri, 20 yaş altı ve 60 yaş üstü bireylere göre daha fazla etkilemektedir. Ayrıca, kadınların ve yükseköğretim mezunu olmayan bireylerin işsizlik sürecinde diğer bireylere nazaran daha fazla kaygı ve üzüntü yaşadıkları yine yapılan araştırmalarda saptanmiştır (Yüksel, 2003: 23). İşsizlik hem birey hem de toplum açısından ciddi boyutlu sorunlar doğuran bir olgudur. İşsizliğin yarattığ 1 bireysel sorunların en başında, kişinin kendisini psikolojik açıdan rahatsız ve huzursuz hissetmesi, özgüven kaybı yaşaması ve ailesine karşı sorumluluklarını yerine getirememesinden kaynaklı yaşadığı endişe gelmektedir (Apaydın, 2018: 162). İşsizliğin kişilerde oluşturduğu cesaretsizlik, motivasyon kaybına ve işsizlik sürecinin daha da uzamasına, bireylerin pasifleşmesine neden olmaktadır. $\mathrm{Bu}$ durum kişinin gelecekte yeni iş bulma sürecin- 
de güven problemine bağlı olarak sorunlar oluşturmakta ve bireyi daha da fakirleştirmektedir. Çünkü bireyde oluşan motivasyon kaybı, ileri ki süreçte kişinin tekrar iş aramaktan vazgeçmesine neden olmaktadır. Bu durum, ülke ekonomisi için tehdit oluşturmaktadır (Bulut, 2011: 25-26).

Böylesine ciddi sonuçları olan işsizlik sorunu çoğunlukla makroekonomik değişkenlerle açıklanmaya çalışılmıştır. Çeşitli nedenlerle işsiz kalmış bireylerin, tekrar iş bulabilmesi için geçen süre yalnızca ülkenin veya bölgenin içinde bulunduğu konjonktür ile ilgili değildir. Bu aynı zamanda bireyin sahip olduğu özelliklerle de ilgilidir. Bu çalışmanın amacı da Türkiye'de işsizlik süresine etki eden bireysel faktörleri araştırmaktır. Bu faktörlerden bazıları bireyin kontrol edebileceği ve değiştirilebilir faktörlerdir. Bunların belirlenmesi bireylere ve politika yapıcılara işsizlik süresini kısaltabilmeleri konusunda yardımcı olacaktır.

\section{METOD}

\subsection{Yaşam Sürdürme Analizleri}

Yaşam sürdürme analizi, araştırılan herhangi bir olayın gerçekleşmesine kadar geçen süre zarfında elde edilen verileri analiz etmek için kullanılan yöntemdir. Yaşam sürdürme analizi, tıp alanında klinik deneme çalışmalarından mühendislikte güvenilirlik değerlendirmeleri, biyoloji ve demografi gibi birçok alanda kullanılmaktadır (Smith 2002: 3). Yaşam sürdürme analizi, açık ve kesin olarak tanımlanan bir zaman başlangıcından bitiş (ölüm, başarısızlık) noktasına kadar geçen süre içinde elde edilen verilerin modellenmesi için de kullanılmaktadır. Böylelikle oluşturulan modellerle yaşam zamanını etkileyen değişkenlerin belirlenebileceği gibi ölüm ya da başarısızlık gibi kesin olarak tanımlanmış bir olayın meydana gelmesi de analiz edilebilmektedir (Bülbül 1999: 5).

Sağ kalım analizi olarak da adlandırılan yaşam sürdürme analizinin amaçları; farklı zaman dilimlerinde yaşam olasılığ 1 tahminlerinin belirlenmesi, yaşam süresi dağılımlarının tahmin edilmesi, bu dağılımların karşılaştırılması, yaşam süresinin açılayıcı (bağımsız) değişkenlerle ilişkisinin değerlendirilmesidir. Çalışmada yaşam sürdürme yöntemlerinden, parametrik olmayan Yaşam Tablosu ve Kaplan-Meier yöntemi ile yarı parametrik olan Cox regresyon yöntemi kullanılmıştır. Yaşam sürdürme analizlerini diğer analizlerden ayıran en temel özellik durdurulmuş yani sansürlenmiş verilerin analize dâhil edilmesidir. Durdurulmuş gözlem tamamlanmamış gözlemdir ve başarısızlık süresi hakkında kısmen bilgi verir. Durdurma, gözlenen bir birimin gözlem süresi boyunca başarısızlığa uğramamasını ifade etmektedir.

\subsubsection{Yaşam Tablosu Yöntemi}

Yaşam tablosu yöntemi, yaşam süresini ölçmek için kullanılan en eski tekniklerden biridir. Bireylerin yaşam sürelerinin belirlenmesi, hayatta kalma çalışmaları, nüfus artışı, doğurganlık, göç, evlilik süreleri, makine çalışma süresi gibi konular üzerine yapılan araştırmalarda oldukça sık kullanılmaktadır (Lee ve Wang 2003: 77). Yaşam Sürdürme analizine Yaşam Tablosu oluşturulmakla başlanmaktadır. Yaşam Tablosu yöntemi, yaşam süresi ile ilgili verileri eşit zaman aralıklarına ayırarak analiz etmekte ve her bir zaman aralığı için yaşam fonksivonları hesaplamaktadır. Yaşam tablosunda $n_{i}$, i. ay başlangicında gözlemlenen iş arayan birey savısını $d_{i}$ , i. ay içinde işe giren birey sayısını ve $w_{i}$ ise $i$. ayda işsiz olarak çalışmadan çıkan birey sayısını göstermektedir. Her zaman aralığ 1 için başarısızlık olasılığı $\left(q_{i}\right)$, yaşam sürdürme olasılı ̆̆ $p_{i}$ ) ve kümülatif yaşam sürdürme olasılığ $\left(S_{i}\right)$ hesaplanmaktadır. Başarısızlık olasılığı formül 1' de gösterilmektedir.

$q_{i}=\frac{d_{i}}{n_{i}-w_{i} / 2}$

Yaşam sürdürme olasılığ $p_{i, 1-} q_{i^{\prime}}$ ye eşittir. $q_{i}$ ve $p_{i}$ değerleri sadece ilgili zaman aralığına ait olasılıkları vermektedir (Özdemir, 2012: 21).

\subsubsection{Kaplan-Meier Yöntemi}

Kaplan-Meier yöntemi, yaşam sürelerine ilişkin verileri zaman aralıklarına bölmeden yaşam ve ölüm fonksiyonlarını hesaplamada kullanılmaktadır. Gözlem sürelerinin tekrarlandığı birimlerin bulunmadığı ve bu sürelerin birbirini büyüklük sırasına göre takip ettikleri durumlarda Yaşam tablolarına tercih edilen bir yöntemdir 
(Bayülken Yetkin 2006: 10). Yöntem, yaşam süresinin tahmin edilmesinde kullanılan Yaşam tablolarına benzerlik göstermektedir. Ancak Kaplan-Meier yöntemini Yaşam tablolarından ayıran en belirgin fark, aralık tahminleri yerine, olayın gerçekleşmesine kadar geçen sürenin kullanılmasıdır. Yaşam tablosu hesaplamalarında, aralıklara karşılık gelen olay sayılarının frekans dağılımı kullanılırken, K-M tahmincisinde söz konusu olayın, gerçekleşmesine kadar geçen süre verileri olduğu gibi kullanılmaktadır (Çelik 2018: 12). Ayrıca K-M' yi Yaşam tablolarından ayıran diğer önemli fark ise, Kaplan-Meier' de tüm bozulma zamanları tek tek değerlendirilmektedir. Bir önceki bozulma zamanından sonra, bir sonraki bozulma anına dek başka bozulma olmaması sebebiyle olasılık değișmemektedir (İnan 2010: 20).

\subsubsection{Cox Regresyon Analizi}

Cox Regresyon analizi, bağımlı değişkeni açıkladığ1 düşünülen bağımsız değişkenlerin etki derecelerini ortaya koyan matematiksel modeller bütünüdür. Araştırmalarda incelenen yaşam süresi modelin bağımlı değişkenini oluşturmaktadır ve belli bir zamandan başlayarak beklenilen olay gerçekleşinceye kadar geçen sürenin takip edilmesini ifade etmektedir.

Cox regresyon modeli fonksiyonu;

$\mathrm{h}(\mathrm{t} ; \mathrm{X})=h_{0(\mathrm{t})} e^{\Sigma_{i=1 \beta i X i}^{p}}$

T: Birey ya da birimin sağ kalım süresi

t: Yaşam süresi olan tesadüfi değişken $T^{\prime}$ nin değeri

X: $\left(X_{1}, X_{2}, X_{3}, \ldots, X_{p}\right)$ bağımsız değişkenler

$\beta$ : Regresyon modelinin katsayıları

$h_{0}(\mathrm{t})$ : Temel hazard fonksiyonu olarak ifade edilmektedir. $\mathrm{Bu}$ ifade, $X^{\prime}$ in olmadığ 1 yani $X=0$ olduğu durumda birim ya da birey için temel hazard fonksiyonu olarak adlandırılmaktadır.

\section{UYGULAMA}

Bu çalışmada, 2015-2018 yıllarına ait Türkiye İstatistik Kurumu Gelir ve Yaşam Koşulları Araştırması anketi panel veri setinden yararlanılarak y1llık işsizlik süresine etki eden faktörler Yaşam Analizi yöntemleri ile incelenmiştir. Kullanılacak veriler üzerinde gerekli düzenlemeler yapilıp analize uygun hale getirilmiştir. Uygulamada parametrik olmayan, Yaşam Tablosu ve Kaplan-Meier yöntemleri ile bireylerin işsiz kalma olasılıkları ve ortalama işsizlik süreleri hesaplanarak, yarı parametrik yöntem olan Cox Regresyon yöntemi ile işsizlik süresine etki eden faktörler değerlendirilmiştir. 2015, 2016, 2017 ve 2018 yıllarında ankete katılan kişilerden 12 ay boyunca işgücüne dâhil olan bireyler ve 15 yaş altındaki bireyler analiz dışında tutulmuştur. İş arayan bireylerin herhangi bir işe girene kadar geçirdikleri işsizlik süresi min. 1 ay max. 12 ay olarak değerlendirilmiştir. Yilsonunda tekrar bir işe girememiş bireylere ait işsizlik süreleri ise durdurulmuş veri olarak tanımlanmıştır. Çalışmada, anket sorularını cevaplayan bireylere dair; yaş, medeni durum, genel sağlık durumu, kronik hastalık durumu, hane halkı tipi, eğitim seviyesi, cinsiyet, ilk düzenli işte çalışılmaya başlanılan yaş, hane halkı sorumlusu, maddi yoksunluk, işsizlik yardımı, SGK kayıtlılık modelde açıklayıcı değişken olarak kullanılıp, bu değişkenlerin işsizlik süresi üzerinde oluşturduğu etki incelenmiştir. Her yıl anket uygulanan bireylerde değişiklik olması sebebiyle ve her yıl bireyin yıllık bazda işsizlik süreleri elde edileceğinden veri seti her referans yıl için ayrı ayrı analiz edilmiştir. Uygulamada kullanılan değişkenler ve değişkenlerin sınıflandırılması Tablo1' de gösterilmektedir. 
Tablo 1. 2015-2016-2017-2018 Yıllarına Ait Değişken ve Değişkenlerin Sınıflandırılması

\begin{tabular}{|c|c|c|c|c|c|}
\hline Değişkenler & Değişken Sınıflandırması & $\mathbf{n}$ & $\%$ & $\begin{array}{l}\text { İşe } \\
\text { Girenlerin } \\
\text { Sayısı }\end{array}$ & $\begin{array}{c}\text { Durdurulmuş } \\
\text { Veri }\end{array}$ \\
\hline \multicolumn{2}{|c|}{ Genel (2015-2016-2017-2018) } & 10908 & $100 \%$ & 3766 & 7142 \\
\hline \multirow{2}{*}{ Cinsiyet } & 0-Erkek & 6683 & 61,27 & 2292 & 4391 \\
\hline & 1-Kadın & 4225 & 38,73 & 1474 & 2751 \\
\hline \multirow{2}{*}{$\begin{array}{l}\text { Medeni } \\
\text { Durum }\end{array}$} & 0-Bekar & 5673 & 52,01 & 1854 & 3819 \\
\hline & 1-Evli & 5235 & 47,99 & 1912 & 3323 \\
\hline \multirow{4}{*}{ Eğitim } & 1-Okuryazar olmayan & 298 & 2,73 & 80 & 218 \\
\hline & $\begin{array}{l}\text { 2-Okuryazar olup bir okul bir okul } \\
\text { bitirmeyen+ } \\
\text { ilkokul }\end{array}$ & 3275 & 30,02 & 1048 & 2227 \\
\hline & $\begin{array}{l}\text { 3-Ortaokul, Mesleki ortaokul } \\
\text { İlköğretim+ } \\
\text { Genel lise, Mesleki lise ve Teknik lise } \\
\end{array}$ & 4999 & 45,83 & 1788 & 3211 \\
\hline & 4-Yüksekokul, Fakülte ve benzeri & 2336 & 21,42 & 850 & 1486 \\
\hline \multirow{3}{*}{ Sağlık Durumu } & 1-Çok iyi + iyi & 8624 & 79,06 & 3031 & 5593 \\
\hline & 2-Ne iyi ne Kötü & 1789 & 16,40 & 605 & 1184 \\
\hline & 3-Kötü + çok kötü & 495 & 4,54 & 130 & 365 \\
\hline \multirow{2}{*}{ Kronik Hastalık } & 1-Hayır & 8588 & 78,73 & 3005 & 5583 \\
\hline & 2-Evet & 2320 & 21,27 & 761 & 1559 \\
\hline \multirow{2}{*}{$\begin{array}{l}\text { Maddi } \\
\text { Yoksunluk }\end{array}$} & $1-$ Yok & 2096 & 19,22 & 910 & 1319 \\
\hline & 2-Var & 8812 & 80,78 & 4345 & 5167 \\
\hline \multirow{5}{*}{ Yaş Grupları } & 1-15-19 Yaş & 1432 & 13,13 & 458 & 974 \\
\hline & 2-20-24 Yaş & 1671 & 15,32 & 588 & 1083 \\
\hline & 3-25-34 Yaş & 2637 & 24,17 & 993 & 1644 \\
\hline & 4-35-54 Yaş & 3944 & 36,16 & 1355 & 2589 \\
\hline & $5-55+$ Yaş & 1224 & 11,22 & 372 & 852 \\
\hline \multirow{2}{*}{ SGK Kayd 1} & 1-Kayıtlı Değil & 2032 & 34,51 & 761 & 1271 \\
\hline & 2-Kayitli & 3856 & 65,49 & 2206 & 1650 \\
\hline \multirow{4}{*}{ Hane Halkı Tipi } & 1-Tek kişilik hane halk1 & 488 & 4,47 & 177 & 311 \\
\hline & $\begin{array}{l}\text { 2-Tek çekirdek aileden oluşan } \\
\text { hane halk1 }\end{array}$ & 8253 & 75,66 & 2892 & 5361 \\
\hline & $\begin{array}{l}\text { 3-En az bir çekirdek aile ve } \\
\text { diğer kişilerden oluşan hane halk1 }\end{array}$ & 1977 & 18,12 & 609 & 1368 \\
\hline & $\begin{array}{l}\text { 4-Çekirdek aile bulunmayan birden } \\
\text { fazla kişiden oluşan hane halkı }\end{array}$ & 190 & 1,74 & 88 & 102 \\
\hline \multirow{2}{*}{ İşsizlik Yardımı } & 1-Almiyor & 9903 & 90,79 & 3288 & 6615 \\
\hline & 2-Aliyor & 1005 & 9,21 & 478 & 527 \\
\hline \multirow{4}{*}{$\begin{array}{l}\text { İlk Düzenli İşte } \\
\text { Çalışmaya } \\
\text { Başlanan Yaş }\end{array}$} & 1-15 Yaş ve Altı & 2787 & 28,94 & 1626 & 1482 \\
\hline & 2-16-25 Yaş & 6324 & 65,67 & 3789 & 3317 \\
\hline & 3-26-35 Yaş & 433 & 4,50 & 280 & 212 \\
\hline & 4-36-45 Yaş & 86 & 0,89 & 61 & 34 \\
\hline \multirow{2}{*}{ Hane Halk1 Sorumlusu } & 1-Hane Halk1 Sorumlusu & 3857 & 35,36 & 1349 & 2508 \\
\hline & 2-Diğeri & 7051 & 64,64 & 2417 & 4634 \\
\hline
\end{tabular}




\subsection{Yılı İçin Bulgular}

2015 yılında Gelir ve Yaşam Koşulları Anketine toplam 14.427 kişi katılmıştır. Anket sorularını cevaplayan kişilerden 1147 kişiye ait veriler uygulamada kullanılmıştır. Çalışmada araştırılan 1147 kişiden 338 (\%29,5) kişi işe giren bireylerden oluşurken geriye kalan $809(\% 70,5)$ kişiye ait veriler durdurulmuş veri olarak tanımlanmıştır.

\subsubsection{Yaşam Tablosu Çözümlemesi}

2015 yılına ait 1147 kişi için yapılan Yaşam Tablosu analizine göre; ay sonunda bireylerin bir kısmının iş gücüne katılması ile 12 ay sonunda geriye kalan bireylerin işsiz kalma olasılıklarında düşüş söz konusudur.

\subsubsection{Kaplan-Meier Çözümlemesi}

İşsizlik süresini etkilediği düşünülen değişkenlere ilk olarak Kaplan-Meier yöntemi uygulanmış ve değişken düzeyleri arasında farklılıklar olup olmadığı Log-Rank test istatistiği ile tespit edilmiştir.

Elde edilen Kaplan-Meier sonuçlarına göre; 2015 anket çalışmasına katılan bireylerin, ortalama işsizlik süresi \pm standart hata [\%95 güven aralığ 1 ]

$$
8,9 \text { ay } \pm 0,14 \text { ay }[8,679-9,214 \text { ay] }
$$

olarak tespit edilmiştir.

Veri setinde kullanılan; medeni durum, hane halkı tipi, maddi yoksunluk, SGK kayıtlılık ve işsizlik yardımı değişkenleri arasında \%95 güven ile anlamlı farklılıklar bulunmaktadır. Tabloyu biraz daha detaylı yorumladığımızda;

Evli olan bireylerin bekâr bireylere göre işsizlik süreleri daha kısadır.

Tek kişilik hane halkının, hane halkı tipi değişkenini oluşturan diğer parametrelere göre işsizlik süresinin daha kısa olduğu söylenebilmektedir.

Ayrıca veri setinde kullanılan; eğitim durumu, genel sağlık durumu, kronik hastalık, yaş, cinsiyet, ilk düzenli işte çalışılmaya başlanılan yaş ve hane halkı sorumlusu değişkenleri arasında \%95 güven aralığında anlamlı farklılıklar olmadığı tespit edilmiştir.

Tablo 2. Yaşam Tablosu-2015 Yilı

\begin{tabular}{|c|c|c|c|}
\hline $\begin{array}{c}\text { Başlangıç } \\
\text { Zaman1 }\end{array}$ & $\begin{array}{c}\text { Gözlenen } \\
\text { Kişi } \\
\text { Say1s1 }\end{array}$ & $\begin{array}{c}\text { Durdurulmuş } \\
\text { Kişi Say1s1 }\end{array}$ & $\begin{array}{c}\text { Kümülatif } \\
\text { İşsiz } \\
\text { Kalma } \\
\text { Olasılıkları }\end{array}$ \\
\hline 0 & 1147 & 0 & 1 \\
\hline 1 & 1147 & 93 & 0,94 \\
\hline 2 & 991 & 104 & 0,88 \\
\hline 3 & 829 & 98 & 0,82 \\
\hline 4 & 674 & 86 & 0,75 \\
\hline 5 & 538 & 40 & 0,73 \\
\hline 6 & 478 & 63 & 0,68 \\
\hline 7 & 384 & 20 & 0,66 \\
\hline 8 & 356 & 24 & 0,62 \\
\hline 9 & 309 & 6 & 0,6 \\
\hline 10 & 295 & 8 & 0,57 \\
\hline 11 & 273 & 6 & 0,56 \\
\hline 12 & 261 & 261 & 0,56 \\
\hline
\end{tabular}


Tablo 3. 2015 Yılı Kaplan-Meier Sonuçları

\begin{tabular}{|c|c|c|c|c|c|}
\hline Değişkenler & Değişken Sınıflandırması & $\begin{array}{l}\text { Ortalama } \\
\text { İşsizlik } \\
\text { Süresi } \\
\text { (Ay) } \\
\end{array}$ & Std hata & $\begin{array}{l}\text { \%95 güven } \\
\text { aralığı }\end{array}$ & $\begin{array}{l}\text { Log- } \\
\text { rank } \\
\text { p }\end{array}$ \\
\hline \multicolumn{2}{|r|}{ Genel } & 8,946 & 0,14 & $8,679-9,214$ & \\
\hline \multirow{2}{*}{ Cinsiyet } & 0-Erkek & 9,045 & 0,16 & $8,734-9,356$ & \multirow{2}{*}{0,108} \\
\hline & 1-Kadın & 8,633 & 0,27 & $8,100-9,166$ & \\
\hline \multirow{2}{*}{$\begin{array}{l}\text { Medeni } \\
\text { Durum }\end{array}$} & 0-Bekâr & 9,308 & 0,18 & $8,954-9,662$ & \multirow{2}{*}{0,002} \\
\hline & 1-Evli & 8,438 & 0,21 & $8,028-8,847$ & \\
\hline \multirow{4}{*}{ Eğitim } & 1-Okuryazar olmayan & 9,247 & 0,67 & $7,936-10,558$ & \multirow{4}{*}{0,152} \\
\hline & $\begin{array}{l}\text { 2-Okuryazar olup bir okul bir okul } \\
\text { bitirmeyen+ ilkokul }\end{array}$ & 9,151 & 0,25 & $8,668-9,634$ & \\
\hline & $\begin{array}{l}\text { 3-Ortaokul, Mesleki ortaokul } \\
\text { İlköğretim+ Genel lise, Mesleki lise ve } \\
\text { Teknik lise }\end{array}$ & 8,845 & 0,21 & $8,438-9,252$ & \\
\hline & 4-Yüksekokul, Fakülte ve benzeri & 8,713 & 0,30 & $8,118-9,307$ & \\
\hline \multirow{3}{*}{ Sağlık Durumu } & 1-Çok iyi + iyi & 8,975 & 0,16 & $8,670-9,281$ & \multirow{3}{*}{0,759} \\
\hline & 2-Ne iyi ne Kötü & 8,514 & 0,33 & $7,860-9,168$ & \\
\hline & 3-Kötü + çok kötü & 9,737 & 0,52 & $8,708-10,766$ & \\
\hline \multirow{2}{*}{ Kronik Hastalık } & 1-Hayır & 8,986 & 0,16 & $8,681-9,291$ & \multirow{2}{*}{0,614} \\
\hline & 2-Evet & 8,809 & 0,29 & $8,249-9,368$ & \\
\hline \multirow{2}{*}{$\begin{array}{l}\text { Maddi } \\
\text { Yoksunluk }\end{array}$} & $1-Y o k$ & 9,869 & 0,23 & $9,418-10,320$ & \multirow{2}{*}{0,000} \\
\hline & 2 -Var & 8,589 & 0,16 & $8,266-8,912$ & \\
\hline \multirow{5}{*}{ Yaş Grupları } & 1-15-19 Yaş & 9,962 & 0,32 & $9,331-10,593$ & \multirow{5}{*}{0,157} \\
\hline & 2-20-24 Yaş & 8,979 & 0,31 & $8,381-8,577$ & \\
\hline & 3-25-34 Yaş & 8,533 & 0,26 & $8,029-9,037$ & \\
\hline & 4-35-54 Yaş & 8,518 & 0,25 & $8,027-9,010$ & \\
\hline & $5-55+$ Yaş & 10,742 & 0,48 & $9,797-9,214$ & \\
\hline \multirow{2}{*}{ SGK Kaydı } & 1-Kayıtlı Değil & 8,117 & 0,39 & $7,363-8,872$ & \multirow{2}{*}{0,000} \\
\hline & 2-Kayitli & 6,773 & 0,24 & $6,300-7,247$ & \\
\hline \multirow{4}{*}{ Hane Halkı Tipi } & 1-Tek kişilik hane halk1 & 7,070 & 877 & $5,350-8,789$ & \multirow{4}{*}{0,001} \\
\hline & $\begin{array}{l}\text { 2-Tek çekirdek aileden oluşan } \\
\text { hane halk1 }\end{array}$ & 8,731 &, 160 & $8,418-9,045$ & \\
\hline & $\begin{array}{l}\text { 3-En az bir çekirdek aile ve } \\
\text { diğer kişilerden oluşan hane halk1 }\end{array}$ & 10,186 &, 258 & $9,680-10,692$ & \\
\hline & $\begin{array}{l}\text { 4-Çekirdek aile bulunmayan birden } \\
\text { fazla kişiden oluşan hane halkı }\end{array}$ & 7,660 &, 844 & $6,006-9,313$ & \\
\hline \multirow{2}{*}{ İşsizlik Yardımı } & 1-Almiyor & 9,057 & 0,14 & $8,782-9,331$ & \multirow{2}{*}{0,001} \\
\hline & 2-Aliyor & 7,316 & 0,54 & $6,256-8,375$ & \\
\hline \multirow{4}{*}{$\begin{array}{l}\text { İlk Düzenli İşte } \\
\text { Çalışmaya } \\
\text { Başlanan Yaş }\end{array}$} & 1-15 Yaş ve Altı & 8,060 & 0,30 & $7,464-8,655$ & \multirow{4}{*}{0,180} \\
\hline & 2-16-25 Yaş & 8,678 & 0,19 & $8,313-9,043$ & \\
\hline & 3-26-35 Yaş & 7,738 & 0,67 & $6,424-9,052$ & \\
\hline & 4-36-45 Yaş & 10,125 & 1,15 & $7,868-12,382$ & \\
\hline \multirow{2}{*}{ Hane Halkı Sorumlusu } & 1-Hane Halk1 Sorumlusu & 9,022 & 0,24 & $8,557-9,488$ & \multirow{2}{*}{0,551} \\
\hline & 2-Diğeri & 8,908 & 0,17 & $8,581-9,235$ & \\
\hline
\end{tabular}




\subsubsection{Cox Regresyon Analizi sonuçları}

Tablo.5 incelendiğinde; değişkenlerde belirlenen referans düzeye göre medeni durum, hane halkı tipi(1), hane halkı tip(2), hane halkı tip(3), genel sağlık durumu(2), ilk düzenli işte çalışılmaya başlanılan yaş(1) değişken düzeylerinin işsizlik süresini \%95 güven düzeyinde etkilediği söylenebilmektedir.

Evli bireyler referans değişken düzeyi olan bekârlara göre 1,51 kat daha kısa sürede iş bulmaktadır.

Tek çekirdek aileden oluşan hane halkı değişken düzeyi referans değişken düzeyi olan tek kişilik hane halkına göre iş bulma süresi 5.1 kat daha uzundur. En az bir çekirdek aile ve diğer kişilerden oluşan hane halkının iş bulma süresi tek kişilik hane halkına göre 5.2 kat daha uzundur. Ayrıca çekirdek aile bulunmayan birden fazla kişiden oluşan hane halkı değişken düzeyi tek kişilik hane halkına göre 2.7 kat daha uzun sürede iş sahibi olabilmektedir.

Sağllk durumu kötü ve çok kötü olan bireyler iş bulma süreleri açısından referans değişken düzeyi olan sağlık durumu çok iyi ya da iyi olan bireylere göre 2.6 kat daha uzun sürede iş bulmaktadir.

Tablo 4. 2015 Yılı Cox Regresyon Sonuçları

\begin{tabular}{|c|c|c|c|c|c|c|}
\hline \multirow[t]{2}{*}{ Değişken Sınıflandırması } & \multirow[b]{2}{*}{$\mathrm{B}$} & \multirow{2}{*}{$\begin{array}{l}\text { Std. } \\
\text { Hata }\end{array}$} & \multirow[b]{2}{*}{ Sig. } & \multirow[b]{2}{*}{$\operatorname{Exp}(B)$} & \multicolumn{2}{|c|}{$\begin{array}{l}\text { Exp(B) için \%95 } \\
\text { Güven Düzeyi }\end{array}$} \\
\hline & & & & & Alt Sinir & Üst Sinır \\
\hline Medeni Durum &, 417 &, 185 & ,024 & 1,518 & 1,057 & 2,181 \\
\hline Hane halkı Tipi & & & ,000 & & & \\
\hline Hane halk1 Tipi(1) &,- 972 & ,332 & ,003 & ,378 & , 197 &, 726 \\
\hline Hane halk1 Tipi(2) & $-1,650$ & ,392 & ,000 & 192 & 089 & 414 \\
\hline Hane halk1 Tipi(3) & $-1,021$ & ,508 & ,044 & 360 & , 133 & 975 \\
\hline Eğitim Durumu & & & 135 & & & \\
\hline Eğitim Durumu(1) &,- 082 & ,476 & ,864 & ,922 &, 362 & 2,344 \\
\hline Eğitim Durumu(2) & ,318 &, 480 & ,508 & 1,374 & ,536 & 3,521 \\
\hline Eğitim Durumu(3) & 347 &, 501 & ,488 & 1,415 & ,530 & 3,776 \\
\hline Sağlık Durumu & & & 068 & & & \\
\hline Sağlık Durumu(1) &, 059 & ,197 & ,764 & 1,061 &, 721 & 1,560 \\
\hline Sağlık Durumu(2) &,- 971 & ,459 & ,034 &, 379 &, 154 & ,931 \\
\hline Kronik Hastalık & ,007 & , 194 & 969 & 1,007 & ,689 & 1,472 \\
\hline Yaş & & & 080 & & & \\
\hline Yaş(1) &, 552 & ,291 & 058 & 1,738 & ,982 & 3,075 \\
\hline Yaş(2) & ,477 & ,291 & ,101 & 1,612 & ,911 & 2,853 \\
\hline Yaş(3) & ,366 &, 316 & ,248 & 1,441 & ,776 & 2,678 \\
\hline Yaş(4) & $-1,720$ & 1,051 &, 102 &, 179 &, 023 & 1,404 \\
\hline Cinsiyet &, 134 &, 155 & ,387 & 1,143 & ,844 & 1,548 \\
\hline Maddi Yoksunluk &, 267 &, 175 &, 128 & 1,306 & ,926 & 1,841 \\
\hline SGK Kayıtlılık & 299 & , 159 &, 061 & 1,348 & ,987 & 1,843 \\
\hline İşsizlik Yardımı & 211 & ,214 & ,324 & 1,234 & ,812 & 1,876 \\
\hline İlk Düzenli İşte Çalışmaya Başlanılan Yaş & & &, 143 & & & \\
\hline $\begin{array}{l}\text { İlk Düzenli İşte Çalışmaya Başlanılan } \\
\text { Yaş(1) }\end{array}$ &,- 357 &, 161 &, 027 &, 700 &, 510 & ,960 \\
\hline $\begin{array}{l}\text { İlk Düzenli İşte Çalışmaya Başlanılan } \\
\text { Yaş(2) }\end{array}$ &,- 365 & ,295 &, 215 & ,694 & ,390 & 1,237 \\
\hline $\begin{array}{l}\text { İlk Düzenli İşte Çalışmaya Başlanılan } \\
\text { Yaş(3) }\end{array}$ &,- 656 &, 736 & ,372 &, 519 &, 123 & 2,194 \\
\hline Hane halk1 Sorumlusu &, 122 &, 142 & ,388 & 1,130 & ,856 & 1,491 \\
\hline
\end{tabular}


16-25 yaş aralığında ilk düzenli işte çalışmaya başlayan bireyler referans değişken düzeyi olan 15 ve altı yaşlarda ilk düzenli işte çalışmaya başlayan bireylere göre 1,4 kat daha uzun sürede iş bulmaktadir.

\subsection{Yılı için Bulgular}

2016 yılında Gelir ve Yaşam Koşulları Anketine toplam 28.785 kişi katılmıştır. 2322 kişiye ait veriler uygulamada kullanılmıştır. 2322 kişiden $833(\% 35,9)$ işe giren bireylerden oluşurken geri- ye kalan $1489(\% 64,1)$ kişiye ait veriler durdurulmuş veri olarak tanımlanmıştır.

\subsubsection{Yaşam Tablosu Çözümlemesi}

2016 yılına ait 2322 kişi için yapılan Yaşam Tablosu analizine göre; ay sonunda bireylerin bir kısmının iş gücüne katılması ile 12 ay sonunda geriye kalan bireylerin işsiz kalma olasılıklarında düşüş olduğu görülmektedir.

Tablo 5. Yaşam Tablosu-2016

\begin{tabular}{|c|c|c|c|c|}
\hline Gözlem Süresi & $\begin{array}{c}\text { Gözlenen } \\
\text { Kişi Say1s1 }\end{array}$ & $\begin{array}{c}\text { Durdurulmuş } \\
\text { Kişi Say1s1 }\end{array}$ & $\begin{array}{c}\text { Kümülatif } \\
\text { İssiz Kalma } \\
\text { Olasilığ1 }\end{array}$ & $\begin{array}{c}\text { Tehlike } \\
\text { Oran1 }\end{array}$ \\
\hline 0 & 2322 & 0 & 1,00 & 0,00 \\
\hline 1 & 2322 & 150 &, 93 &, 07 \\
\hline 2 & 2019 & 206 &, 86 &, 08 \\
\hline 3 & 1666 & 179 &, 78 &, 10 \\
\hline 4 & 1331 & 134 &, 68 &, 07 \\
\hline 5 & 1107 & 87 &, 62 &, 05 \\
\hline 6 & 966 & 134 &, 59 &, 09 \\
\hline 7 & 753 & 50 &, 55 &, 07 \\
\hline 8 & 661 & 24 &, 49 &, 07 \\
\hline 9 & 594 & 28 &, 48 &, 03 \\
\hline 10 & 527 & 16 &, 48 &, 03 \\
\hline 11 & 494 & 4 & & 0,00 \\
\hline 12 & 477 & 477 & & \\
\hline
\end{tabular}


Tablo 6. 2016 Y1lı Kaplan-Meier Sonuçları

\begin{tabular}{|c|c|c|c|c|c|}
\hline Değişkenler & Değişken Sınıflandırması & $\begin{array}{l}\text { Ortalama } \\
\text { İşsizlik } \\
\text { Süresi } \\
\text { (Ay) }\end{array}$ & Std hata & $\begin{array}{l}\text { \%95 güven } \\
\text { aralığı }\end{array}$ & $\begin{array}{c}\text { Log- } \\
\text { rank } \\
\text { p }\end{array}$ \\
\hline \multicolumn{2}{|r|}{ Genel } & 8,355 & 0,098 & $8,163-8,547$ & \\
\hline \multirow{2}{*}{ Cinsiyet } & 0-Erkek & 8,194 & 0,128 & $7,942-8,446$ & \multirow{2}{*}{0,560} \\
\hline & 1-Kadın & 8,581 & 0,151 & $8,285-8,877$ & \\
\hline \multirow{2}{*}{$\begin{array}{l}\text { Medeni } \\
\text { Durum }\end{array}$} & 0-Bekâr & 8,956 & 0,126 & $8,708-9,203$ & \multirow{2}{*}{0,000} \\
\hline & 1-Evli & 7,587 & 0,151 & 7,291-7,882 & \\
\hline \multirow{4}{*}{ Eğitim } & 1-Okuryazar olmayan & 9,313 & 0,585 & $8,167-10,458$ & \multirow{4}{*}{0,458} \\
\hline & $\begin{array}{l}\text { 2-Okuryazar olup bir okul bir okul } \\
\text { bitirmeyen+ } \\
\text { ilkokul }\end{array}$ & 8,099 & 0,192 & $7,722-8,476$ & \\
\hline & $\begin{array}{l}\text { 3-Ortaokul, Mesleki ortaokul } \\
\text { İlköğretim+ Genel lise, Mesleki lise ve } \\
\text { Teknik lise }\end{array}$ & 8,353 & 0,145 & $8,068-8,637$ & \\
\hline & 4-Yüksekokul, Fakülte ve benzeri & 8,540 & 0,195 & $8,159-8,922$ & \\
\hline \multirow{3}{*}{ Sağlık Durumu } & 1-Çok iyi + iyi & 8,335 & 0,109 & $8,122-8,549$ & \multirow{3}{*}{0,268} \\
\hline & 2-Ne iyi ne Kötü & 8,151 & 0,254 & $7,653-8,649$ & \\
\hline & 3-Kötü + çok kötü & 9,583 & 0,437 & $8,727-10,439$ & \\
\hline \multirow{2}{*}{ Kronik Hastalık } & 1-Hayır & 8,379 & 0,109 & $8,166-8,592$ & \multirow{2}{*}{0,464} \\
\hline & 2-Evet & 8,267 & 0,225 & $7,825-8,709$ & \\
\hline \multirow{2}{*}{$\begin{array}{l}\text { Maddi } \\
\text { Yoksunluk }\end{array}$} & $1-Y o k$ & 9,149 & 0,206 & $8,746-9,552$ & \multirow{2}{*}{0,000} \\
\hline & 2-Var & 8,149 & 0,111 & $7,933-8,366$ & \\
\hline \multirow{5}{*}{ Yaş Grupları } & 1-15-19 Yaş & 8,592 & 0,273 & $8,056-9,127$ & \multirow{5}{*}{0,860} \\
\hline & 2-20-24 Yaş & 8,563 & 0,248 & $8,076-9,050$ & \\
\hline & 3-25-34 Yaş & 7,892 & 0,212 & $7,478-8,307$ & \\
\hline & 4-35-54 Yaş & 8,249 & 0,161 & $7,933-8,564$ & \\
\hline & $5-55+$ Yaş & 8,983 & 0,261 & $8,473-9,494$ & \\
\hline \multirow{2}{*}{ SGK Kaydı } & 1-Kayıtlı Değil & 7,407 & 0,245 & $6,925-7,888$ & \multirow{2}{*}{0,000} \\
\hline & 2-Kayıtlı & 5,850 & 0,148 & $5,560-6,141$ & \\
\hline \multirow{4}{*}{ Hane Halkı Tipi } & 1-Tek kişilik hane halkı & 7,994 & 0,440 & $7,132-8855$ & \multirow{4}{*}{0,165} \\
\hline & $\begin{array}{l}\text { 2-Tek çekirdek aileden oluşan } \\
\text { hane halk1 }\end{array}$ & 8,285 & 0,114 & $8,062-8,508$ & \\
\hline & $\begin{array}{l}\text { 3-En az bir çekirdek aile ve } \\
\text { diğer kişilerden oluşan hane halk1 }\end{array}$ & 8,757 & 0,220 & $8,326-9,188$ & \\
\hline & $\begin{array}{l}\text { 4-Çekirdek aile bulunmayan birden } \\
\text { fazla kişiden oluşan hane halkı }\end{array}$ & 8,188 & 0,758 & $6,701-9,674$ & \\
\hline \multirow{2}{*}{ İşsizlik Yardımı } & 1-Almiyor & 8,529 & 0,102 & $8,330-8,729$ & \multirow{2}{*}{0,000} \\
\hline & 2-Aliyor & 6,623 & 0,317 & $6,002-7,244$ & \\
\hline \multirow{4}{*}{$\begin{array}{l}\text { İlk Düzenli İşte } \\
\text { Çalışmaya } \\
\text { Başlanan Yaş }\end{array}$} & 1-15 Yaş ve Altı & 7,723 & 0,209 & $7,314-8,133$ & \multirow{3}{*}{0,754} \\
\hline & 2-16-25 Yaş & 7,840 & 0,130 & $7,585-8,096$ & \\
\hline & 3-26-35 Yaş & 8,280 & 0,466 & $7,367-9,193$ & \\
\hline & 4-36-45 Yaş & 6,744 & 1,158 & $4,474-9,013$ & \\
\hline \multirow{2}{*}{ Hane Halk1 Sorumlusu } & 1-Hane Halk1 Sorumlusu & 7,856 & 0,165 & $7,532-8,180$ & \multirow{2}{*}{0,000} \\
\hline & 2-Diğeri & 8,638 & 0,121 & $8,402-8,875$ & \\
\hline
\end{tabular}




\subsubsection{Kaplan-Meier Çözümlemesi}

Elde edilen Kaplan-Meier sonuçlarına göre; 2016 anket çalışmasına katılan bireylerin, ortalama işsizlik süresi \pm standart hata [\%95 güven aralığ 1 ]

$$
8,3 \text { ay } \pm 0,098 \text { ay }[8,163-8,547 \text { ay }]
$$

olarak tespit edilmiştir.

Açıklayıcı değişkenlerden, medeni durum, maddi yoksunluk, SGK kayıtlılık, işsizlik yardımı, hane halkı sorumlusu değişkenleri arasında \%95 güven düzeyinde anlamlı farklılıklar bulunmaktadir.

Yani, bekâr bireylerin evli bireylere göre iş bulma süreleri daha uzundur.

SGK' ya kayıtlı olan bireyler kayıtlı olmayan bireylere göre daha kısa sürede işgücüne katılmaktadır.

Hane halkı sorumlusu birey hanede yaşayan diğer bireylere nazaran daha kısa sürede iş bulmaktadır.

Tablo 7. 2016 Yılı Cox Regresyon Sonuçları

\begin{tabular}{|c|c|c|c|c|c|c|}
\hline \multirow{2}{*}{ Değişken Sınıflandırması } & \multirow[b]{2}{*}{ B } & \multirow{2}{*}{$\begin{array}{l}\text { Std. } \\
\text { Hata }\end{array}$} & \multirow[b]{2}{*}{ Sig. } & \multirow[b]{2}{*}{$\operatorname{Exp}(B)$} & \multicolumn{2}{|c|}{$\begin{array}{l}\text { Exp(B) için } 95,0 \% \\
\text { Güven Düzeyi }\end{array}$} \\
\hline & & & & & Alt Sinır & Üst Sinır \\
\hline Medeni Durum & 240 & ,098 & ,015 & 1,271 & 1,048 & 1,542 \\
\hline HanehalkıTipi & & &, 462 & & & \\
\hline HanehalkıTipi(1) &,- 158 & 182 & ,385 & 853 & ,597 & 1,220 \\
\hline HanehalkıTipi(2) &,- 291 & 203 & 151 & ,747 &, 502 & 1,112 \\
\hline HanehalkıTipi(3) &,- 228 & 351 & ,516 & ,796 & 400 & 1,584 \\
\hline Eğitim Durumu & & & , 133 & & & \\
\hline Eğitim Durumu(1) & ,475 & ,348 & 172 & 1,609 & 813 & 3,183 \\
\hline Eğitim Durumu(2) & ,405 & ,349 & ,246 & 1,499 & ,756 & 2,970 \\
\hline Eğitim Durumu(3) & 605 &, 360 & ,092 & 1,832 & ,905 & 3,708 \\
\hline Sağlık Durumu & & & 160 & & & \\
\hline Sağlık Durumu(1) &,- 001 &, 130 & ,992 & ,999 & ,774 & 1,288 \\
\hline Sağlık Durumu(2) &,- 512 & ,277 & 065 & ,599 & ,348 & 1,032 \\
\hline Kronik Hastalık & , 148 & 125 & 235 & 1,159 & ,908 & 1,480 \\
\hline Yaş & & & ,076 & & & \\
\hline Yaş(1) &,- 151 & 168 & 368 & 860 & 619 & 1,194 \\
\hline Yaş(2) &, 179 & 157 &, 253 & 1,197 &, 880 & 1,627 \\
\hline Yaş(3) &,- 068 & , 153 & 657 & ,934 & 692 & 1,261 \\
\hline Yaş(4) &,- 025 & 190 & ,894 & ,975 & 672 & 1,414 \\
\hline Cinsiyet &, 142 &, 095 &, 134 & 1,153 & ,957 & 1,389 \\
\hline Maddi Yoksunluk & 202 & ,118 & 087 & 1,223 & ,971 & 1,541 \\
\hline SGK Kayıtl111k & ,479 &, 100 & 000 & 1,615 & 1,328 & 1,964 \\
\hline İşsizlik Yardımı & 065 & 125 & 604 & 1,067 & 836 & 1,362 \\
\hline İlk Düzenli İşte Çalışmaya Başlanılan Yaş & & & ,108 & & & \\
\hline $\begin{array}{l}\text { İlk Düzenli İşte Çalışmaya Başlanılan } \\
\text { Yaş(1) }\end{array}$ &,- 249 & ,098 & ,011 & ,780 & ,644 & ,944 \\
\hline $\begin{array}{l}\text { İlk Düzenli İşte Çalışmaya Başlanılan } \\
\text { Yaş(2) }\end{array}$ &,- 281 &, 197 &, 154 &, 755 &, 513 & 1,111 \\
\hline $\begin{array}{l}\text { İlk Düzenli İşte Çalışmaya Başlanılan } \\
\text { Yaş(3) }\end{array}$ &,- 307 & ,349 & ,380 & ,736 & ,371 & 1,459 \\
\hline $\begin{array}{l}\text { İlk Düzenli İşte Çalışmaya Başlanılan } \\
\text { Yaş(4) }\end{array}$ & ,808 & 1,067 & ,449 & 2,243 & ,277 & 18,138 \\
\hline Hane halk1 Sorumlusu &,- 161 & ,113 & 154 & 851 & 682 & 1,062 \\
\hline
\end{tabular}




\subsubsection{Cox Regresyon Analizi sonuçları}

2016 y1lı Cox Regresyon Analizi tablosunda p değerleri incelendiğinde; medeni durum, SGK kayıtlılık, ilk düzenli işte çalışılmaya başlanılan yaş değişkenlerinin işsizlik süresini \%95 güven düzeyinde etkilediği söylenebilmektedir.

Tablo biraz daha detaylı incelendiğinde;

Evli bireylerin işsiz kalma süreleri bekâr bireylere göre 1,2 kat daha kısa olmaktadır.

SGK' ya kayıtlı olmayan bireyler kayıtlı olan bireylere göre 1,6 kat daha uzun süre iş aramaktadir.

16-25 yaş aralığında ilk düzenli işte çalışmaya başlayan bireylerin referans değişken düzeyi olan 15 ve altı yaşlarda ilk düzenli işte çalışma- ya başlayan bireylere göre işsizlik süreleri 1,3 kat daha uzundur.

\subsection{Yılı için Bulgular}

2017 yılında Gelir ve Yaşam Koşulları Anketine toplam 44.055 kişi katılmıştır. 3766 kişiye ait veriler uygulamada kullanılmıştır. Çalışmada araştırılan 3766 kişiden $1234(\% 35,9)$ kişi işe giren bireylerden oluşurken geriye kalan 2532 (\%64,1) kişiye ait veriler durdurulmuş veri olarak tanımlanmıştır.

\subsubsection{Yaşam Tablosu Çözümlemesi}

2017 yılına ait 3766 kişi için yapılan Yaşam Tablosu analizine göre; ay sonunda bireylerin bir kısmının iş gücüne katılması ile 12 ay sonunda geriye kalan iş arayan bireylerin işsiz kalma olasılıklarında düşüş söz konusudur.

Tablo 8. Yaşam Tablosu-2017

\begin{tabular}{|c|c|c|c|c|}
\hline Gözlem Süresi & $\begin{array}{c}\text { Gözlenen } \\
\text { Kişi Sayıs1 }\end{array}$ & $\begin{array}{c}\text { Durdurulmuş } \\
\text { Kişi Sayıs1 }\end{array}$ & $\begin{array}{c}\text { Kümülatif } \\
\text { İssiz Kalma } \\
\text { Olasilığ } 1\end{array}$ & $\begin{array}{c}\text { Tehlike } \\
\text { Oran1 }\end{array}$ \\
\hline 0 & 3766 & 0 & 1,00 & 0,00 \\
\hline 1 & 3766 & 279 &, 95 &, 05 \\
\hline 2 & 3301 & 327 &, 89 &, 07 \\
\hline 3 & 2768 & 276 &, 81 &, 09 \\
\hline 4 & 2269 & 250 &, 70 &, 07 \\
\hline 5 & 1872 & 164 &, 63 &, 07 \\
\hline 6 & 1581 & 275 &, 60 &, 11 \\
\hline 7 & 1155 & 97 &, 56 &, 04 \\
\hline 8 & 1013 & 48 &, 54 &, 04 \\
\hline 9 & 902 & 38 &, 52 &, 04 \\
\hline 10 & 832 & 18 &, 51 &, 03 \\
\hline 11 & 782 & 11 &, 51 & 0,00 \\
\hline 12 & 749 & 749 & & \\
\hline
\end{tabular}


Tablo 9. 2017 Y1lı Kaplan-Meier Sonuçları

\begin{tabular}{|c|c|c|c|c|c|}
\hline \multicolumn{2}{|c|}{ Değişken Sınıflandırması } & \begin{tabular}{l|} 
Ortalama \\
İşsizlik \\
Süresi \\
(Ay)
\end{tabular} & Std hata & $\begin{array}{l}\text { \%95 güven } \\
\text { aralığı }\end{array}$ & $\begin{array}{l}\text { Log- } \\
\text { rank } \\
\mathbf{p}\end{array}$ \\
\hline \multicolumn{2}{|r|}{ Genel } & 8,618 & 0,076 & $8,470-8,767$ & \\
\hline \multirow{2}{*}{ Cinsiyet } & 0 -Erkek & 8,483 &, 100 & $8,287-8,678$ & \multirow{2}{*}{0,029} \\
\hline & 1-Kadın & 8,817 & 117 & $8,589-9,046$ & \\
\hline \multirow{2}{*}{$\begin{array}{l}\text { Medeni } \\
\text { Durum }\end{array}$} & 0-Bekar & 9,105 & ,096 & $8,918-9,293$ & \multirow{2}{*}{0,000} \\
\hline & 1-Evli & 7,912 & , 123 & $7,671-8,153$ & \\
\hline \multirow{4}{*}{ Eğitim } & 1-Okuryazar olmayan & 8,821 &, 528 & 7,786-9856 & \multirow{4}{*}{0,000} \\
\hline & $\begin{array}{l}\text { 2-Okuryazar olup bir okul bir okul } \\
\text { bitirmeyen+ ilkokul }\end{array}$ & 8,254 &, 152 & $7,956-8,552$ & \\
\hline & $\begin{array}{l}\text { 3-Ortaokul, Mesleki ortaokul } \\
\text { İlköğretim+ } \\
\text { Genel lise, Mesleki lise ve Teknik lise }\end{array}$ & 8,491 &, 110 & $8,276-8,707$ & \\
\hline & 4-Yüksekokul, Fakülte ve benzeri & 9,223 &, 150 & $8,929-9,518$ & \\
\hline \multirow{3}{*}{ Sağlık Durumu } & 1-Çok iyi + iyi & 8,640 & 084 & $8,475-8,805$ & \multirow{3}{*}{0,985} \\
\hline & 2-Ne iyi ne Kötü & 8,431 & 200 & $8,038-8,824$ & \\
\hline & 3-Kötü + çok kötü & 8,746 & ,380 & $8,001-9,491$ & \\
\hline \multirow{2}{*}{ Kronik Hastalık } & 1-Hayır & 8,608 &, 085 & $8,442-8,775$ & \multirow{2}{*}{0,651} \\
\hline & 2-Evet & 8,661 &, 169 & $8,330-8,993$ & \\
\hline \multirow{2}{*}{$\begin{array}{l}\text { Maddi } \\
\text { Yoksunluk }\end{array}$} & 1-Yok & 9,201 &, 174 & $8,860-9,542$ & \multirow{2}{*}{0,000} \\
\hline & 2-Var & 8,492 & 084 & $8,327-8,657$ & \\
\hline \multirow{5}{*}{ Yaş Grupları } & 1-15-19 Yaş & 8,562 & ,209 & $8,152-8,973$ & \multirow{5}{*}{0,199} \\
\hline & 2-20-24 Yaş & 8,610 & , 190 & $8,237-8,982$ & \\
\hline & 3-25-34 Yaş & 8,428 &, 162 & $8,110-8,745$ & \\
\hline & 4-35-54 Yaş & 8,648 & , 126 & $8,402-8,894$ & \\
\hline & $5-55+$ Yaş & 8,992 & 214 & $8,573-9,410$ & \\
\hline \multirow{2}{*}{ SGK Kaydı } & 1-Kayıtlı Değil & 7,217 &, 192 & $6,840-7,593$ & \multirow{2}{*}{0,000} \\
\hline & 2-Kayıtlı & 6,233 &, 125 & $5,988-6,478$ & \\
\hline \multirow{4}{*}{ Hane Halkı Tipi } & 1-Tek kişilik hane halkı & 8,795 & ,343 & $8,122-9,468$ & \multirow{4}{*}{0,663} \\
\hline & $\begin{array}{l}\text { 2-Tek çekirdek aileden oluşan } \\
\text { hane halk1 }\end{array}$ & 8,604 &, 088 & $8,431-8,776$ & \\
\hline & $\begin{array}{l}\text { 3-En az bir çekirdek aile ve } \\
\text { diğer kişilerden oluşan hane halk1 }\end{array}$ & 8,660 &, 175 & $8,317-9,004$ & \\
\hline & $\begin{array}{l}\text { 4-Çekirdek aile bulunmayan birden } \\
\text { fazla kişiden oluşan hane halkı }\end{array}$ & 8,322 &, 556 & $7,232-9,411$ & \\
\hline \multirow{2}{*}{ İşsizlik Yardımı } & 1-Almiyor & 8,711 & 079 & $8,555-8,867$ & \multirow{2}{*}{0,000} \\
\hline & 2-Alıyor & 7,679 & 250 & $7,189-8,170$ & \\
\hline \multirow{4}{*}{$\begin{array}{l}\text { İlk Düzenli İşte } \\
\text { Çalışmaya } \\
\text { Başlanan Yaş }\end{array}$} & 1-15 Yaş ve Altı & 8,023 &, 166 & $7,698-8,348$ & \multirow{4}{*}{0,253} \\
\hline & 2-16-25 Yaş & 8,203 &, 102 & $8,004-8,402$ & \\
\hline & 3-26-35 Yaş & 8,510 &, 352 & $7,820-9,201$ & \\
\hline & 4-36-45 Yaş & 9,047 & ,833 & $7,414-10,679$ & \\
\hline \multirow{2}{*}{ Hane Halk1 Sorumlusu } & 1-Hane Halk1 Sorumlusu & 8,390 &, 135 & $8,126-8,654$ & \multirow{2}{*}{0,034} \\
\hline & 2-Diğeri & 8,737 & ,092 & $8,557-8,917$ & \\
\hline
\end{tabular}




\subsection{Kaplan-Meier Çözümlemesi}

Elde edilen Kaplan-Meier sonuçlarına göre; 2017 anket çalışmasına katılan bireylerin,

ortalama işsizlik süresi \pm standart hata [\%95 güven aralığ]

$$
8,6 \text { ay } \pm 0,076 \text { ay }[8,470-8,767 \text { ay }]
$$

olarak tespit edilmiştir.

Modelde kullanılan; cinsiyet, medeni durum, eğitim, maddi yoksunluk, SGK kayıtlılık, işsizlik yardımı, hane halkı sorumlusu değişkenleri ara- sında \%95 güven düzeyinde anlamlı farklılıklar bulunmaktadır.

\subsection{Cox Regresyon Analizi sonuçları}

2017 y1lı Cox Regresyon Analizi tablosuna göre; medeni durum, SGK kayıtlılık değişkenlerinin işsizlik süresini $\% 95$ güven düzeyinde etkilediği söylenebilmektedir.

Bekâr bireylerin evli bireylere göre işsiz kalma süreleri 1,3 kat daha uzundur.

SGK kayıtlı olan bireylerin kayıtlı olmayan bireylere göre işsizlik süreleri 1,4 kat daha kısadır.

Tablo 10. 2017 Yılı Cox Regresyon Sonuçları

\begin{tabular}{|c|c|c|c|c|c|c|}
\hline \multirow{2}{*}{ Değişken Sınıflandırması } & \multirow[b]{2}{*}{ B } & \multirow{2}{*}{$\begin{array}{l}\text { Std. } \\
\text { Hata }\end{array}$} & \multirow[b]{2}{*}{ Sig. } & \multirow[b]{2}{*}{$\operatorname{Exp}(B)$} & \multicolumn{2}{|c|}{$\begin{array}{l}\text { Exp(B) için } 95,0 \% \\
\text { Güven Düzeyi }\end{array}$} \\
\hline & & & & & Alt Sinir & Üst Sinır \\
\hline Medeni Durum & 271 &, 081 & ,001 & 1,312 & 1,119 & 1,537 \\
\hline HanehalkıTipi & & & ,544 & & & \\
\hline HanehalkıTipi(1) &,- 180 & , 159 &, 257 & ,835 & ,612 & 1,140 \\
\hline HanehalkıTipi(2) &,- 253 & 175 & 149 & ,777 & ,551 & 1,095 \\
\hline HanehalkıTipi(3) &,- 158 & 261 & ,545 & 854 & ,512 & 1,425 \\
\hline Eğitim Durumu & & & 831 & & & \\
\hline Eğitim Durumu(1) &,- 163 & ,249 & ,511 & 849 &, 522 & 1,383 \\
\hline Eğitim Durumu(2) &,- 103 & ,251 & ,682 & ,902 &, 552 & 1,475 \\
\hline Eğitim Durumu(3) &,- 136 & ,262 & ,603 & 873 & ,522 & 1,458 \\
\hline Sağlık Durumu & & & ,991 & & & \\
\hline Sağlık Durumu(1) &,- 012 & ,116 & ,919 & ,988 &, 787 & 1,241 \\
\hline Sağlık Durumu(2) &,- 027 & 222 & ,904 & 974 & 630 & 1,505 \\
\hline Kronik Hastalık & ,018 & ,111 & 873 & 1,018 & ,819 & 1,265 \\
\hline Yaş & & & 816 & & & \\
\hline Yaş(1) &, 033 &, 127 & ,794 & 1,034 & ,806 & 1,325 \\
\hline Yaş(2) &,- 026 & , 123 & ,834 & 974 & ,766 & 1,240 \\
\hline Yaş(3) &,- 085 & ,122 & ,489 & ,919 & ,723 & 1,168 \\
\hline Yaş(4) &,- 110 & ,155 & ,477 & ,895 & ,660 & 1,214 \\
\hline Cinsiyet &,- 007 & 082 & ,935 & ,993 & 847 & 1,166 \\
\hline Maddi Yoksunluk & ,132 &, 102 & ,194 & 1,141 & ,935 & 1,394 \\
\hline SGK Kayıtlılık & ,325 & ,078 & ,000 & 1,385 & 1,188 & 1,614 \\
\hline İşsizlik Yardımı &,- 015 & 102 & ,881 & ,985 & 807 & 1,203 \\
\hline İlk Düzenli İşte Çalışmaya Başlanılan Yaş & & &, 791 & & & \\
\hline $\begin{array}{l}\text { İlk Düzenli İşte Çalışmaya Başlanılan } \\
\text { Yaş(1) }\end{array}$ &,- 079 & 080 & 320 & 924 & ,790 & 1,080 \\
\hline $\begin{array}{l}\text { İlk Düzenli İşte Çalışmaya Başlanılan } \\
\text { Yaş(2) }\end{array}$ &, 044 &, 161 & ,784 & 1,045 & ,762 & 1,433 \\
\hline $\begin{array}{l}\text { İlk Düzenli İşte Çalışmaya Başlanılan } \\
\text { Yaş(3) }\end{array}$ &, 127 & ,457 & ,781 & 1,136 & ,463 & 2,782 \\
\hline $\begin{array}{l}\text { İlk Düzenli İşte Çalışmaya Başlanılan } \\
\text { Yaş(4) }\end{array}$ &, 085 &, 721 & ,906 & 1,089 &, 265 & 4,474 \\
\hline Hane halk1 Sorumlusu &,- 092 & ,094 & ,332 & ,913 & ,759 & 1,098 \\
\hline
\end{tabular}




\subsection{Yılı için Bulgular}

2018 yılında Gelir ve Yaşam Koşulları Anketine toplam 44.620 kişi katılmıştır. 3673 kişiye ait veriler uygulamada kullanılmıştır. Çalışmada araştırılan 3673 kişiden $1361(\% 37,1)$ işe giren bireylerden oluşurken geriye kalan $2312(\% 62,9)$ kişiye ait veriler durdurulmuş veri olarak tanımlanmıştır.

\subsubsection{Yaşam Tablosu Çözümlemesi}

2018 yılına ait 3673 kişi için yapılan Yaşam Tablosu analizine göre; ay sonunda bireylerin bir kısmının iş gücüne katılması ile 12 ay sonunda geriye kalan bireylerin işsiz kalma olasılıklarında düşüş olduğu görülmektedir.

Tablo 11. Yaşam Tablosu-2018

\begin{tabular}{|c|c|c|c|c|}
\hline Gözlem Süresi & $\begin{array}{l}\text { Gözlenen } \\
\text { Kişi Sayıs1 }\end{array}$ & $\begin{array}{l}\text { Durdurulmuş } \\
\text { Kişi Sayısı }\end{array}$ & $\begin{array}{l}\text { Kümülatif } \\
\text { İssiz Kalma } \\
\text { Olasılığı }\end{array}$ & $\begin{array}{c}\text { Tehlike } \\
\text { Oranı }\end{array}$ \\
\hline 0 & 3673 & 0 & 1,00 & 0,00 \\
\hline 1 & 3673 & 219 & ,95 & ,05 \\
\hline 2 & 3278 & 298 & ,89 & ,07 \\
\hline 3 & 2767 & 282 & 80 &, 10 \\
\hline 4 & 2234 & 207 &, 74 &, 08 \\
\hline 5 & 1855 & 129 & 67 &, 10 \\
\hline 6 & 1557 & 276 & ,59 &, 13 \\
\hline 7 & 1107 & 97 & ,55 &, 05 \\
\hline 8 & 955 & 61 &, 52 & ,06 \\
\hline 9 & 836 & 45 & ,49 & ,06 \\
\hline 10 & 744 & 14 & ,47 & ,04 \\
\hline 11 & 701 & 11 & ,46 & ,02 \\
\hline 12 & 673 & 673 & ,46 & 0,00 \\
\hline
\end{tabular}


Tablo 12. 2018 Y11 Kaplan-Meier Sonuçları

\begin{tabular}{|c|c|c|c|c|c|}
\hline Değişkenler & Değişken Sınıflandırması & \begin{tabular}{l|} 
Ortalama \\
İşsizlik \\
Süresi \\
(Ay)
\end{tabular} & Std hata & $\begin{array}{l}\text { \%95 güven } \\
\text { aralığı }\end{array}$ & $\begin{array}{c}\text { Log- } \\
\operatorname{rank} \\
p\end{array}$ \\
\hline \multicolumn{2}{|r|}{ Genel } & 8,266 & 077 & $8,116-8,416$ & \\
\hline \multirow{2}{*}{ Cinsiyet } & 0 -Erkek & 8,200 & 102 & $8,001-8,399$ & \multirow{2}{*}{0,296} \\
\hline & 1-Kadın & 8,352 &, 116 & $8,124-8,580$ & \\
\hline \multirow{2}{*}{$\begin{array}{l}\text { Medeni } \\
\text { Durum }\end{array}$} & 0-Bekar & 8,835 & ,098 & $8,643-9,026$ & \multirow{2}{*}{0,000} \\
\hline & 1-Evli & 7,501 &, 120 & $7,266-7,736$ & \\
\hline \multirow{4}{*}{ Eğitim } & 1-Okuryazar olmayan & 8,106 &, 510 & $7,107-9,105$ & \multirow{4}{*}{0,004} \\
\hline & $\begin{array}{l}\text { 2-Okuryazar olup bir okul bir okul } \\
\text { bitirmeyen+ ilkokul }\end{array}$ & 7,906 &, 156 & $7,599-8,212$ & \\
\hline & $\begin{array}{l}\text { 3-Ortaokul, Mesleki ortaokul İlköğretim+ } \\
\text { Genel lise, Mesleki lise ve Teknik lise }\end{array}$ & 8,257 &, 113 & $8,036-8,477$ & \\
\hline & 4-Yüksekokul, Fakülte ve benzeri & 8,583 &, 147 & $8,295-8,872$ & \\
\hline \multirow{3}{*}{ Sağllk Durumu } & 1-Çok iyi + iyi & 8,226 & ,086 & $8,058-8,394$ & \multirow{3}{*}{0,104} \\
\hline & 2-Ne iyi ne Kötü & 8,259 & ,193 & $7,881-8,638$ & \\
\hline & 3-Kötü + çok kötü & 9,006 & ,355 & $8,311-9,701$ & \\
\hline \multirow{2}{*}{ Kronik Hastalık } & 1-Hayır & 8,237 & ,086 & $8,069-8,405$ & \multirow{2}{*}{0,463} \\
\hline & 2-Evet & 8,371 & ,170 & $8,038-8,705$ & \\
\hline \multirow{2}{*}{$\begin{array}{l}\text { Maddi } \\
\text { Yoksunluk }\end{array}$} & $1-$ Yok & 8,856 & ,192 & $8,479-9,233$ & \multirow{2}{*}{0,001} \\
\hline & 2-Var & 8,164 & 083 & $8,000-8,327$ & \\
\hline \multirow{5}{*}{ Yaş Grupları } & 1-15-19 Yaş & 8,582 & ,208 & $8,174-8,989$ & \multirow{5}{*}{0,282} \\
\hline & 2-20-24 Yaş & 8,118 & ,206 & $7,714-8,522$ & \\
\hline & 3-25-34 Yaş & 7,863 &, 154 & $7,561-8,164$ & \\
\hline & 4-35-54 Yaş & 8,247 &, 130 & $7,992-8,502$ & \\
\hline & $5-55+$ Yaş & 8,974 & ,203 & $8,576-9,372$ & \\
\hline \multirow{2}{*}{ SGK Kaydı } & 1-Kayıtlı Değil & 6,850 &, 183 & $6,491-7,209$ & \multirow{2}{*}{0,000} \\
\hline & 2-Kayitli & 5,914 & ,112 & $5,694-6,134$ & \\
\hline \multirow{4}{*}{ Hane Halkı Tipi } & 1-Tek kişilik hane halkı & 8,967 & 315 & $8,349-9,584$ & \multirow{4}{*}{0,303} \\
\hline & $\begin{array}{l}\text { 2-Tek çekirdek aileden oluşan } \\
\text { hane halk1 }\end{array}$ & 8,184 & 088 & $8,012-8,356$ & \\
\hline & $\begin{array}{l}\text { 3-En az bir çekirdek aile ve } \\
\text { diğer kişilerden oluşan hane halk1 }\end{array}$ & 8,563 &, 190 & $8,190-8,936$ & \\
\hline & $\begin{array}{l}\text { 4-Çekirdek aile bulunmayan birden } \\
\text { fazla kişiden oluşan hane halkı }\end{array}$ & 7,041 &, 515 & $6,032-8,050$ & \\
\hline \multirow{2}{*}{ İşsizlik Yardımı } & 1-Almiyor & 8,428 &, 081 & $8,270-8,585$ & \multirow{2}{*}{0,000} \\
\hline & 2-Aliyor & 6,827 & ,227 & $6,382-7,273$ & \\
\hline \multirow{4}{*}{$\begin{array}{l}\text { İlk Düzenli İşte } \\
\text { Çalışmaya } \\
\text { Başlanan Yaş }\end{array}$} & 1-15 Yaş ve Altı & 7,743 & ,161 & $7,428-8,059$ & \multirow{4}{*}{0,902} \\
\hline & $2-16-25$ Yaş & 7,828 &, 100 & $7,631-8,024$ & \\
\hline & 3-26-35 Yaş & 7,844 & ,337 & $7,18,-8,505$ & \\
\hline & 4-36-45 Yaş & 6,338 & ,854 & $4,663-8,012$ & \\
\hline \multirow{2}{*}{ Hane Halkı Sorumlusu } & 1-Hane Halk1 Sorumlusu & 8,027 &, 135 & $7,762-8,292$ & \multirow{2}{*}{0,020} \\
\hline & 2-Diğeri & 8,379 & ,093 & $8,197-8,560$ & \\
\hline
\end{tabular}




\subsubsection{Kaplan-Meier Çözümlemesi}

Elde edilen Kaplan-Meier sonuçlarına göre; 2018 anket çalışmasına katılan bireylerin, ortalama işsizlik süresi \pm standart hata [\%95 güven aralığ 1 ]

\section{8,2 ay $\pm 0,77$ ay $[8,116-8,416$ ay]}

olarak tespit edilmiştir.
Açılayıcı değiş̧kenlerden; medeni durum, eğitim seviyesi, maddi yoksunluk, SGK kayıtlılık, işsizlik yardımı, hane halkı sorumlusu değişkenleri arasında \%95 güven düzeyinde anlamlı farklilıklar bulunmaktadır.

Tablo 13. 2018 Yilı Cox Regresyon Sonuçları

\begin{tabular}{|c|c|c|c|c|c|c|}
\hline \multirow[t]{2}{*}{ Değişken Sınıflandırması } & \multirow[b]{2}{*}{ B } & \multirow{2}{*}{$\begin{array}{l}\text { Std. } \\
\text { Hata }\end{array}$} & \multirow[b]{2}{*}{ Sig. } & \multirow[b]{2}{*}{$\operatorname{Exp}(B)$} & \multicolumn{2}{|c|}{$\begin{array}{l}\text { Exp(B) için } 95,0 \% \\
\text { Güven Düzeyi }\end{array}$} \\
\hline & & & & & Alt Sinır & Üst Sinır \\
\hline Medeni Durum & ,274 &, 074 &, 000 & 1,315 & 1,136 & 1,521 \\
\hline HanehalkıTipi & & & ,496 & & & \\
\hline HanehalkıTipi(1) & 074 & , 148 & 615 & 1,077 &, 807 & 1,438 \\
\hline Hanehalk1Tipi(2) &,- 049 &, 168 & ,772 & ,953 & 686 & 1,323 \\
\hline HanehalkıTipi(3) & , 166 & 226 & ,463 & 1,180 & ,758 & 1,839 \\
\hline Eğitim Durumu & & &, 831 & & & \\
\hline Eğitim Durumu(1) & 202 &, 254 & ,428 & 1,223 &, 743 & 2,013 \\
\hline Eğitim Durumu(2) & 220 & 255 & ,389 & 1,246 & ,756 & 2,053 \\
\hline Eğitim Durumu(3) & 243 & ,263 &, 356 & 1,275 & ,761 & 2,135 \\
\hline Sağlık Durumu & & & ,201 & & & \\
\hline Sağlık Durumu(1) &,- 077 & , 109 & ,482 & ,926 & ,748 & 1,146 \\
\hline Sağlık Durumu(2) &,- 377 & 211 & 074 & 6,686 & ,454 & 1,037 \\
\hline Kronik Hastalık & ,132 &, 105 & ,209 & 1,141 & ,929 & 1,401 \\
\hline Yaş & & &, 141 & & & \\
\hline Yaş(1) & ,239 &, 122 & ,050 & 1,270 & 1,000 & 1,612 \\
\hline Yaş(2) & , 136 & 110 & 215 & 1,146 & ,924 & 1,421 \\
\hline Yaş(3) & 035 & 114 & ,757 & 1,036 & 828 & 1,295 \\
\hline Yaş(4) &,- 037 & ,144 & ,797 & ,964 & ,727 & 1,278 \\
\hline Cinsiyet &,- 009 & 073 & ,905 & ,991 &, 859 & 1,144 \\
\hline Maddi Yoksunluk &, 157 &, 101 &, 121 & 1,170 & ,959 & 1,428 \\
\hline SGK Kayıtlılık & 243 & 075 & ,001 & 1,275 & 1,101 & 1,476 \\
\hline İşsizlik Yardımı &, 075 & ,089 & ,399 & 1,078 & ,905 & 1,284 \\
\hline İlk Düzenli İşte Çalışmaya Başlanılan Yaş & & & 680 & & & \\
\hline $\begin{array}{l}\text { İlk Düzenli İşte Çalışmaya Başlanılan } \\
\text { Yaş(1) }\end{array}$ & ,012 & ,074 &, 870 & 1,012 & ,876 & 1,170 \\
\hline $\begin{array}{l}\text { İlk Düzenli İşte Çalışmaya Başlanılan } \\
\text { Yaş(2) }\end{array}$ &,- 055 & ,143 & ,702 & ,947 & ,715 & 1,254 \\
\hline $\begin{array}{l}\text { İlk Düzenli İşte Çalışmaya Başlanılan } \\
\text { Yaş(3) }\end{array}$ & ,477 &, 363 & , 188 & 1,612 & ,792 & 3,281 \\
\hline $\begin{array}{l}\text { İlk Düzenli İşte Çalışmaya Başlanılan } \\
\text { Yaş(4) }\end{array}$ & ,411 & ,724 &, 570 & 1,509 & ,365 & 6,238 \\
\hline Hane halk1 Sorumlusu &,- 087 & 088 & ,325 & 917 & ,772 & 1,089 \\
\hline
\end{tabular}




\subsubsection{Cox Regresyon Analizi sonuçları}

2018 yılı Cox Regresyon Analizi tablosu incelendiğinde; medeni durum, yaş(1), SGK kayıtlılık, değişken düzeylerinin işsizlik süresini \%95 güven düzeyinde etkilediği söylenebilmektedir.

Tablo biraz daha detaylı incelendiğinde;

Evli bireylerin işsiz kalma süreleri bekâr bireylere göre 1,3 kat daha kısa olmaktadır.

20-24 yaş aralığındaki bireyler iş arayan 15-19 yaş aralığındaki bireylere göre 1,2 kat daha hızlı iş bulmaktadır.

SGK' ya kayıtlı olmayan bireyler kayıtlı olan bireylere göre 1,3 kat daha uzun süre iş aramaktadır.

\section{SONUÇ ve ÖNERILER}

2015-2016-2017 ve 2018 yılları Kaplan-Meier sonuçları değerlendirildiğinde, en uzun işsizlik süresinin 2015 yılına (8,9 ay), en kısa işsizlik süresinin ise 2018 yılına (8,2 ay) ait olduğu söylenebilmektedir. Ayrıca, yıllar itibariyle değişken düzeyleri açısından en uzun ortalama işsizlik süreleri değişkenlik göstermektedir. Fakat tüm yıllarda en kısa ortalama işsizlik süresi çalıştığ son işinde SGK kaydı bulunan bireylere aittir. Kaplan-Meier sonuçlarına göre; tüm yıllarda açılayııı değişkenler olarak kullanılan; medeni durum, SGK kayıtlılık, işsizlik yardımı ve maddi yoksunluk değişkenleri arasında \%95 güven düzeyinde anlamlı farklılıklar bulunmaktadır. Elde edilen Cox Regresyon sonuçlarına göre;

2015 yılında referans değişken düzeylerine göre, medeni durum, hane halkı tip(1), hane halkı tip(2), genel sağlık durumu(2), ilk düzenli işte çalışılmaya başlanılan yaş(1) değişken düzeylerinin,

2016 yılında referans değişken düzeylerine göre, medeni durum, SGK kayıtlılık, ilk düzenli işte çalışılmaya başlanılan yaş(1) değişken düzeylerinin,

2017 yılında, medeni durum, SGK kayıtlılık değişkenlerinin, 2018 yllında ise medeni durum, Yaş(1), SGK kayıtlılık, değişkenlerinin işsizlik süresini \%95 güven düzeyinde etkilediği söylenebilmektedir. 4 yıl birlikte değerlendirildiğinde; medeni durum ve SGK kayıtlılık değişkenlerinin tüm yıllarda işsizlik süresini etkileyen faktörler olduğu görülmektedir. Yani,

Bekâr bireylerin iş bulma süreleri evli bireylere göre daha uzun bir zaman dilimini kapsamaktadır. Bunun başlıca sebeplerinden biri bekâr bireylerin çoğunlukla aileleriyle birlikte yaşamaları ve maddi yönden aileleri tarafından desteklenmeleri sebebiyle iş kaygısı yaşamayarak iş arama konusunda daha seçici davranmaları gösterilebilmektedir.

Yine çalıştığı son işinde SGK kaydı bulunan bireyler kaydı bulunmayan bireylere göre daha kısa sürede işgücüne katılabilmektedir. Yani, SGK kaydı olan (deneyim kazanmış) bireyler SGK kaydı olmayan (deneyim kazanmamış) bireylere göre daha hızlı işe yerleşmektedir.

Ayrıca diğer açıklayıcı değişkenlerden; cinsiyet, kronik hastalık durumu, maddi yoksunluk, işsizlik yardımı ve hane halkı sorumlusu değişkenlerin 4 yıl itibariyle işsizlik süresi üzerinde herhangi bir etki yaratmadığı gözlemlenmektedir.

Sonuçta karar mercilerine, bekâr bireylere ve Sosyal Güvenlik Kurumu' na kayıtlı olmadan çalışan işsiz bireylere odaklanılması önerilebilir. Bu bireylerin kendi bilgi ve becerileri dâhilinde uygun işlere en kısa sürede yerleşebilmelerini sağlayacak çalışmalar yapılabilir.

İşsizlik süresine etki eden bazı faktörler, bireyin kontrol edebileceği faktörlerken, bazıları ise bireyin kontrol edemeyeceği dişsal faktörlerdir. Çalışma sonuçlarına göre birey sahip olduğu bazı özelliklerini değiştirerek işsizlik süresini etkileme şansına sahiptir. 


\section{KAYNAKÇA}

APAYDIN, F., (2018), Türkiye'de İşsizliğin Karakteristiklerinin Karşılaştırmalı Analizi, Süleyman Demirel Üniversitesi Sosyal Bilimler Enstitüsü Dergisi, Sayı:30, 159-200

AYVAZ, Z, (1990), Türkiye'de İstihdam ve İşsizlik Sorunlarl, Yüksek Lisans, İstanbul Üniversitesi-S.B.E.-Say1sal Yöntemler A.B.D.

BAYÜLKEN YETKIN, B. (2006). Cox Regresyon Analizi ve Bir Uygulamast. Mimar Sinan Üniversitesi. Fen Bilimleri Enstitüsü. Yüksek Lisans Tezi.

BULUT, V., (2011), Türkiye'de İsssizlik Süresini Etkileyen Faktörlerin Yaşam Çözümlemesi İle İncelenmesi, Yüksek Lisans, Hacettepe Üniversitesi-İstatistik A.B.D.

BÜLBÜL,S.E, (1999) İstatistiksel Bașarısızlık zamanı modelleri ve finansal analizlerde uygulaması, Doktora, Marmara Üniversitesi-S.B.E-Ekonometri A.B.D.

ÇELIK, K.,(2009), Makro İktisada Giriş, Trabzon, Murathan Yayınevi, 2. Bask1, ISBN:978-605-5937-31-7

ÇELIK, S. (2018). Sağkalım Analizinde Açılanan Varyans Oranının İncelenmesi. Van Yüzüncü Yıl Üniversitesi. Sağllk Bilimleri Enstitüsü. Yüksek Lisans Tezi.

İNAN, D. (2010). İç İlişki Durumunda Cox Oransal Hazard Modeli İ̧̧in Farklı Tahmin Edicilerin Incelenmesi. Marmara Üniversitesi. Fen Bilimleri Enstitüsü. Doktora Tezi

LEE E. T. \& WANG J. W. (2003). Statistical Methods for Survival Data Analysis. New Jersey: John Wiley \& Sons, Inc.

ÖZDEMIR, O., (2012). Sağkalım Analizi Yöntemleri-I, İyi Klinik Uygulamaları Dergisi, 9.Say1, 21-33.

SMITH, P.J., (2002), Analysis Failure And Survival Data, Chapman \& Hall/CRC. London, ISBN: 1-584-075-9

Yüksel, İ. (2003). İșssizliğin Psiko-Sosyal Sonuçlarının İncelenmesi (Ankara Örneği), C.Ü. İktisadi ve İdari Bilimler Dergisi, 4(2), 21-38 